\section{Natural Variability in Yield of Lowbush Blueberries}

\author{
Paul R. Hepler ${ }^{1}$ and David E. Yarborough ${ }^{2}$ \\ Department of Plant, Soil, and Environmental Sciences, University of \\ Maine, Orono, ME 04469
}

Additional index words. Vaccinium angustifolium, wild blueberries, yield potential, natural selection, plant breeding

\begin{abstract}
One hundred lowbush blueberry (Vaccinium angustifolium Ait.) clones were randomly sampled from a commercial field to estimate potential productivity. Yield data exhibited a normal distribution ranging from 300 to $17,000 \mathrm{~kg} \cdot \mathrm{ha}^{-1}$ with a mean of $7726 \mathrm{~kg} \cdot \mathrm{ha}^{-1}$. Commercial use of selected clones or improved cultivars through new plantings, interplanting into existing clones, or replacement of low-yielding clones in native stands and increasing the intensity of field management would increase the yielding potential of native lowbush blueberry fields.
\end{abstract}

Lowbush blueberries are produced on 42,000 ha of native stands in Maine and in the Maritime Provinces and Quebec. Blueberries are pruned to the soil surface every other year, so a crop is produced every 2 nd year. Lowbush blueberry yields fluctuate among clones and years but yields have generally increased in recent years (DeGomez et al., 1990). Although yield fluctuations may be attributed to weather conditions, no significant correlations were found between yield and climatic conditions in Canada (Hall et al., 1982).

Production from native fields is low compared to cultivated highbush blueberries $(V$. corymbosum) or rabbiteye blueberries (V. ashei). Lowbush blueberries in Maine yielded an average of $960 \mathrm{~kg} \cdot \mathrm{ha}^{-1}$ from 1969 to 1974 (Metzger and Ismail, 1976) and $1580 \mathrm{~kg} \cdot \mathrm{ha}$ from 1985 to 1989 (DeGomez et al., 1990).

Barker et al. (1964) found lowbush yields in rod-square plots in New Brunswick weighed from 43 to $11,000 \mathrm{~kg} \cdot \mathrm{ha}^{-1}$ over 5 years. Highbush in Michigan yielded $\approx 2300$ to $8800 \mathrm{~kg} \cdot \mathrm{ha}^{-1}$ (Nelson, 1979) and rabbiteye in Arkansas 7700 to $13,800 \mathrm{~kg} \cdot \mathrm{ha}$ (Moore, 1975).

Selection and breeding of lowbush blueberries have produced several high yielding named cultivars. 'Augusta' has yielded 14,000 $\mathrm{kg} \cdot \mathrm{ha}^{-1}$ (Aalders et al., 1978), and progeny of selections have produced from 4600 to $8400 \mathrm{~kg} \cdot \mathrm{ha}^{-1}$ (Hall, 1983). Field trials of native clones under intensive management have produced yields of $6600 \mathrm{~kg} \cdot \mathrm{ha}^{-1}$ (Smagula and Hepler, 1978).

This project was initiated to study genetic and phenotypic variability in productivity of $V$. angustifolium. One hundred discrete blueberry clones were randomly located in a commercial blueberry barren in Deblois, Maine, in May 1974. A $38 \times 38 \times 13-\mathrm{cm}$

Received for publication 12 July 1990. Maine Agricultural Experiment Station Contribution no. 1490 The cost of publishing this paper was defrayed in part by the payment of page charges. Under postal regulations, this paper therefore must be hereby marked advertisement solely to indicate this fact.

'Associate Professor Emeritus of Horticulture.

${ }^{2}$ Associate Scientist. a box, and transported to the Maine Agricultural Experiment Station in Jonesboro. The clones in their containers were randomly plunged into the soil as a $10 \times 10$ clone sod block. Plants were fertilized from 1974 through 1976 with a 473-ppm solution of $21 \mathrm{~N}-7 \mathrm{P}-7 \mathrm{~K}$ soluble fertilizer $\left(7.46 \% \mathrm{NO}_{3}\right.$, $1.63 \% \mathrm{NH}_{4}, 11.9 \%$ urea) to saturation three times per season and hand-weeded and watered as needed through Aug. 1976. Plants were pruned by burning in Apr. 1975. In May 1976, a screen cage was placed over the block of clones and a hive of honeybees was placed within for the duration of flowering to effect maximum pollination. Blueberries were harvested with a hand-held rake in Aug. 1976. The data were subjected to descriptive statistical analysis using SAS Proc Univariate (SAS Institute, Inc., 1982). The mean yield of the 100 blueberry clones was $7726 \mathrm{~kg} \cdot \mathrm{ha}^{-1}$ with a standard deviation of 3240 and a coefficient of variation of $42 \%$. Yields ranged from 400 to $17,000 \mathrm{~kg} \cdot \mathrm{ha}^{-1}$, which indicates the extreme variability one would expect in an unselected species. The yields were normally distributed (Prob $>$ D 0.15 ) with minimal skewness $(0.168)$ or kurtosis $(-0.008)$. The frequency distribution (Fig. 1) shows that $>30 \%$ of the clones sod was removed from each clone, placed in

Fig. 1. Frequency distribution of 100 blueberry clones. yielded at the $7500 \mathrm{~kg} \cdot \mathrm{ha}^{-1}$ midpoint with 9\% at the $2500 \mathrm{~kg}$-ha-' midpoint and 10\% at the $12,000 \mathrm{~kg} \cdot \mathrm{ha}^{-1}$ midpoint.

A small percentage of the clones had yields equivalent to those of released, cultivated cultivars of blueberries. The disparity between the low average yield obtained for fields in commercial production and the high yields obtained in this study may be due to the differences in pollination, irrigation, and plant cover.

The blueberry clones in this study were subjected to a high density of bees for pollination. Lowbush blueberries can set up to $100 \%$ of their blossoms, but set in the field seldom exceeds $40 \%$ with native pollinators and $70 \%$ when supplemented with honeybees (Wood, 1969). Moisture is necessary for flower bud development-and for increasing the weight of the berries (Benoit et al., 1984). Because the plants were hand-watered, moisture was always available for maximum production of fruit.

A third factor affecting yield is the plant cover. Plant cover depends on the number of years a field has been in production. Blueberry clones spread very slowly (Hall et al., 1979); fields in production for 50 or more years may have nearly $100 \%$ cover, but younger fields usually have $<50 \%$ cover. Data from vegetation transects taken in commercial blueberry fields in Maine indicated that cover averaged from $40 \%$ to $70 \%$ (Yarborough and Bhowmik, 1989). Increasing the blueberry cover by the introduction of improved selections could greatly improve the productivity of native lowbush blueberry fields.

Horticulturists (Barker et al., 1964; Kender, 1967; Trevett., 1972) have indicated a need for domesticating the lowbush blueberry using matted row culture with improved varieties. Except for a few small plantings (Vandenberg, 1982), this type of culture has not been adopted by the industry. The limited availability of plant material, the high cost of establishment, and the slow rate of plant spread have prevented growers from establishing cultivated, lowbush blueberry fields. Recent information indicates that seedlings and micropropagated lowbush be-

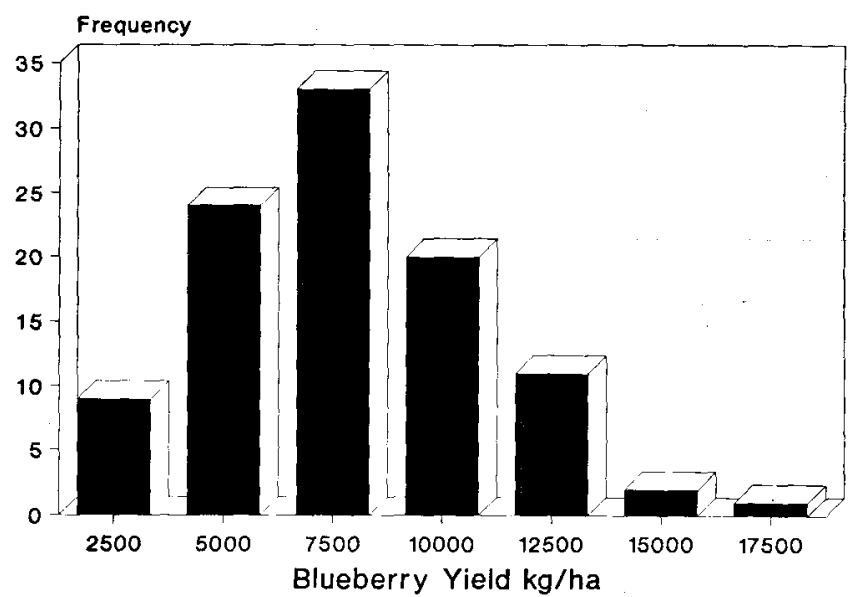


come established and spread faster than conventional rooted cuttings (Morrison and Smagula, 1985).

The presented data indicate that native stands under more intensive management are capable of producing much greater yields than obtained now. Removing the less productive clones and interplanting high-yielding clones into the interclonal spaces in existing fields would greatly increase the average yields. Using improved micropropagated selections or seedlings from polycrosses of selected clones in natural stands will preserve the variable nature of the lowbush blueberry fruit and markedly increase yields.

\section{Literature Cited}

Aalders, L.E., I.V. Hall, and A.C. Brydon. 1978. Yield of native clones of lowbush blueberry under cultivation. Fruit Var. J. 32(3):64-67.

Barker, W.G., I.V. Hall, L.E. Aalders, and G.W. Wood. 1964. The lowbush blueberry industry in Eastern Canada. Econ. Bot. 18:357-365.

Benoit, G.R., W.J. Grant, A. A. Ismail, and D.E. Yarborough. 1984. Effect of soil moisture on the potential and actual yield of lowbush blueberries. Can. J. Plant Sci. 64:683-689.

DeGomez, T., H.Y. Forsythe, D. Lambert, E Osgood, J. Smagula, and D. Yarborough. 1990. Introduction to growing blueberries in Maine. Wild Blueberry Fact Sheet no. 222. Univ. of Maine Coop. Ext. Serv., Orono.

Hall, I.V. 1983. Genetic improvement of the lowbush blueberry, Vaccinium angustifolium. Can. J. Plant Sci. 63:1091-1092.

Hall, I.V., L.E. Aalders, and K.B. McRae. 1982. Lowbush blueberry production. Eastern Canada as related to certain weather data. Can. J. Plant Sci. 62:809-812.

Hall, I.V., L.E. Aalders, N.L. Nickerson, and S.P.V. Kloet. 1979. The biological flora of Canada. 1. Vacinnium angustifolium Ait., Sweet lowbush blueberry. can. Field-nat. 93:415-430.

Kender, W.J. 1967. On the domestication of the lowbush blueberry. Fruit Var. Hort. Dig. 21:7576.

Metzger, H.B. and A.A. Ismail. 1976. Management practices and cash operating costs in lowbush blueberry production. Maine Life Sci. Agr. Expt. Sta. Bul. 723.

Moore. J.N. 1975. Research on highbush and rabbiteye blueberries in Arkansas. Proc. N. Amer. Blueberry Work Conf. Michigan State Univ., E. Lansing. p. 40-44.

Morrison, S.R. and J.M. Smagula. 1985. Morphology, growth and rhizome development of the lowbush blueberry tissue culture plants, seedlings and rooted cuttings. HortScience 21:734.

Nelson, J.W. 1979. Blueberry variety performance in Michigan. Ed. J.N. Moore. Proc. 4th N. Amer. Blueberry Res. Workers Conf. Univ. Arkansas, Fayetteville. p. 1-6.

SAS Institute. 1982. The Univariate procedure. SAS users guide: Basics, 1982 (ed.). SAS Institute, Inc., Cary, N.C. p. 575-583.

Smagula, J.M. and P.R. Hepler. 1978. Comparison of urea and sulfur-coated urea as nitrogen source for lowbush blueberries growing on a Colton gravelly loam sand. J. Amer. Soc. Hort. Sci. 103:818-820.

Trevett, M.F. 1972. The integrated management of lowbush blueberry fields: A review and forecast. Maine Life Sci. Agr. Expt. Sta. Bul. 699.

Vandenberg, J. 1982. Cultivated lowbush blueberries-A new crop for Ontario. Highlights of Agr. Res. in Ontario. 5(3):1-3.

Wood, G.W. 1969. Evidence of increased fruit feet of hexazinone on weed populations and on lowbush blueberries in Maine. Acta Hort. 241:344-349. 